\title{
The Concept of Illness and Musical Intervention Among Members of the Iyayi Society of the Esan, Edo State of Nigeria.
}

\author{
Charles Onomudo Aluede, and Omoera Osakue Stevenson, Ambrose Alli University, \\ Nigeria
}

\begin{abstract}
Absract
The healing effect of music on man is very significant in most parts of the world. However, not much has been done by African researchers to study music and the ailments it heals especially among the peoples of Nigeria. This work examines the therapeutic effect of music in Iyayi society of Esan community, Edo state of Nigeria. The concept of illness, illness causation, the healing system and the specific songs used in healing of some ailments are investigated. It was found that music in the society is used as medicine as well as accompaniment to healing rites. The study concludes that Iyayi songs hold much promise for the development of pan African music therapy and as such should be notated. It therefore recommends that Iyayi songs are of immense benefits in the treatment and management of labour pains, insomnia and general debilities.
\end{abstract}

\section{Introduction}

The healing powers of music have become an ever-growing subject in academic discourse and have given rise to the term music therapy which has formed an alternative way of healing in orthodox medical praxis. Today, scholars have developed interest in the extra musical functions of music. Such interest has culminated in studies on music and healing. This has led to the formulation of theories on the science of sound in healing by Mamman (1997:1) and that which states that music heals more efficaciously in cultural contexts (Scott, 2006:4), which this study relies on as its theoretical framework. This paper examines the processes of music in healing in Iyayi society. It identifies the ailments which Iyayi can effectively treat, documents and analyzes some Iyayi songs used for such healing thus contributing to the bibliography of therapeutic music in Nigeria.

\section{Definition of Music Therapy}

Alvin (1975:4) defines music therapy as the controlled use of music in the treatment, education, training and rehabilitation of children and adults suffering from physical, mental or emotional disorders. Mereni (2004:9) indicates that the word therapy comes from the Greek word "therapeia" which means "healing", in the same sense as treatment of a disease: a curative intervention for the purpose of healing a sickness or restoring health. 


\section{Origin of Esan and the Iyayi Society in Esanland}

The term Esan is applied to people in five local government areas in Edo Central senatorial district of Edo state. Esan is located in the tropical zone of the northern part of the Nigerian forest region (Okoduwa, 1997:45). What exactly is Iyayi and when did the religious society evolve in Esan? Iyayi in Esan means "I believe" or "faith in God" - (Iyayi Osenebua).

For congruent presentation, Osenughegbe religious movement changed to Iyayi for fear of arrest similar to the situation in Benin; hence, a decade after the arrest of Osenughegbe (Idubor), the high priest in Benin, a different name was adopted to facilitate registration. One of the Iyayi worship songs, "Orea yi shoshi" as translated shows the linguistic evidence of borrowing and adaptation of the Urhobo word in an Esan song:

\author{
Text in Esan \\ Oare ha yi shoshi \\ Ose a so tie o \\ Osenobula kpa \\ na mien bha gbon
}

\author{
Translation \\ Even though it is in the church \\ It is God one calls on. \\ It is only one God \\ that is found in the world.
}

Although Ishoshi is non-existent in Esan, according to Ofosu (2001:78), "Ishoshi is the Urhobo word for church. Thus "Ishoshi Erhi" means spiritual church". The Esan word for church is Otue. Interestingly, Esan is not in any way a neighbour of the Urhobo to allow for cross cultural borrowing and adaptation of language. Thus, Iyayi society of the Esan is undoubtedly an out growth of Igbe Ubiesha religious movements of Kokori, Delta State. This is why the groups in Esan pay homage to Kokori during their annual meetings in Kokori (Echekwube; 1994:22 and Nabofa 2003:238). In recent times, however, because of economic hardship and political restructuring, this homage has been de-emphasized and conventions are now held at Usugbenu, Agwa and other areas chosen by the head priests.

\section{Concept of Illness and its Etiology in Esan}

Among the Esan, four classes of disease causation are discernable by both the healers and the generality of the people. These are:

\section{Emianmhen \\ 2. Emianmhen - Ason \\ 3. Emianmhen - Elimhin \\ 4. Emianmhen-Arialusi}

1 Emianmhen is sickness, which is natural and very tractable. The ailments under this category are those contacted from poor living conditions, heredity and through sexual promiscuity.

2 Emianmhen - Ason which means, night sickness, refers to diseases caused by witches and wizards. In this case, while the sickness may manifest itself 
in natural form, careful prognosis and diagnosis is required so that the related forces can be appeased to facilitate prompt healing.

3 Emianmhen - Arinmhin or Emianmhen - Elimhin, according to the different dialects in Esan, is sickness caused by ancestors, gods and spirits. This type of sickness is often contacted through neglect of ancestors, village gods, eating a totem animal, breaking binding rules, having canal knowledge of a brother's wife, infidelity or willful destruction of a relative's property.

4. Emianmhen-Arialusi. This is the kind of sickness carried over from past earth life.

There is a general belief in Esan that when a spouse dies and is not mourned by the widow or widower or when one commits an unexposed crime before death, when he reincarnates he begins to suffer and he can only be cured by offering of sacrifices.

\section{The Healing Systems in Iyayi Society}

Iyayi society has two major kinds of healing procedures and they are: healing basically through music and music as an accompaniment to healing rites. What follows are the use of music in the management of illnesses.

\section{Music as Audio Analgesic in Labour Pains}

Audio analgesic could be simply explained as sound one hears that helps to reduce pains considerably. Explaining the action of musical sounds on human brain and the entire body, Zatorre (2005:312) remarks:

...sound waves from a musical instrument after being introduced into neural impulses by the inner ear, travels through several ... stations in the brainstem and midbrain to reach the auditory cortex. The auditory cortex contains distinct sub-regions that are important for decoding and representing the various aspects of the complex sound. In turn, information from the auditory cortex interacts with many other brain areas, especially the frontal lobe, for memory formation and interpretation. The orbito-frontal region is one of the many sections involved in emotional evaluation (Zatorre, 2005: 312).

Consequently, when a person who suffers from pains is faced with the appreciation and interpretation of sound, the source of pain is forgotten because the brain, in particular and the entire body bathes in the music provided. It is generally known that pregnancy is no sickness and falling into labour is no sickness either. However, falling into labour has its associated excruciating pains and health complications. Among members of Iyayi society, labour pains during delivery are managed through intense music and dance using selected songs from their repertoire which have relevance to delivery and motherhood. In what follows, we would report cases of ailment brought to Iyayi society and how they have been cured with the application of music. 


\section{Case Study 1}

Around $10.25 \mathrm{pm}$ on the 30th of August, 2007, Mrs. Obehi Aaron (nee Egbadon) of Idumebo, Irrua, was led by Mrs. Lucy Egbadon to the home of Oga Williams Urieto . Mrs. Aaron who lives with her husband in Lagos was sent home to her parents in Edo State when her expected date of delivery was very close. The expectant mother had registered in the pre-natal arm of the out patients department of Irrua specialist teaching hospital. For fear of high fee of discharge from the hospital and the incidence of caesarean section which is sometimes performed on pregnant women, Mrs. Aaron was led by her mother to the home of Oga Williams Urieto.

Investigation and diagnosis. At the time when Mrs. Egbadon led her daughter to the healing home, Mrs. Obehi Aaron was already feeling uncomfortable with her condition. Her stomach was big and Oga Williams Urieto observed that the baby has not positioned its head downwards towards the cervix for proper engagement to facilitate delivery.

Treatment. At 1.15 am on the 31st August, 2007, on the order of Oga Williams Urieto, Mrs., Obehi Aaron was stripped of her blouse and bra by two women who also rubbed Uden (palm kernel oil) on her stomach down through her legs to touch the floor with their palms. She was given a mixture of Uden3, Ogbon4 bi amen (palm kernel oil, clay and water) to drink, after which they performed the following songs for her.

OMON AIGBE MEA
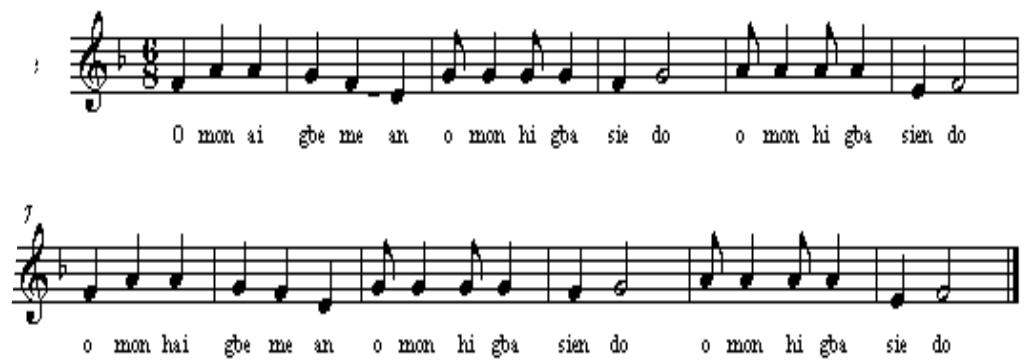

Text in Esan

Omon ai gbe mea

Omon hi gba sien do

Omon hi gba sien do
Translation

Baby do not kill me

Children do not kill Alligator pepper

Children do not kill Alligator pepper

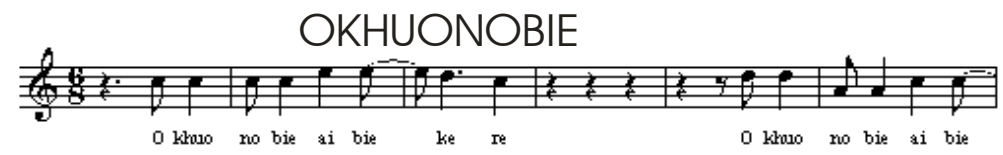




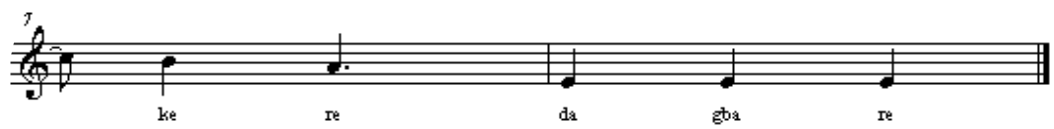

$\begin{array}{ll}\text { Text in Esan } & \text { Translation } \\ \text { Okhuo no bie } & \text { Woman in labour } \\ \text { Ai bie kere } & \text { Do not reserve anything } \\ \text { Okhuo no bie } & \text { Woman in labour } \\ \text { Ai bie kere } & \text { Do not reserve anything } \\ \text { Dagbare } & \text { Let the baby come out }\end{array}$

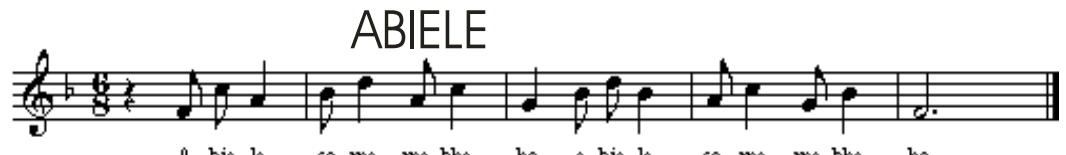

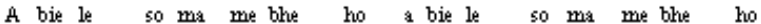

Text in Esan

Translation

Abiele

So ma me bhe ho

Delivery news

Abiele

Isn't pleasant to the ears?

So ma me bhe ho

Delivery news

Isn't pleasant to the ears?

$\mathrm{OBIOMON}$
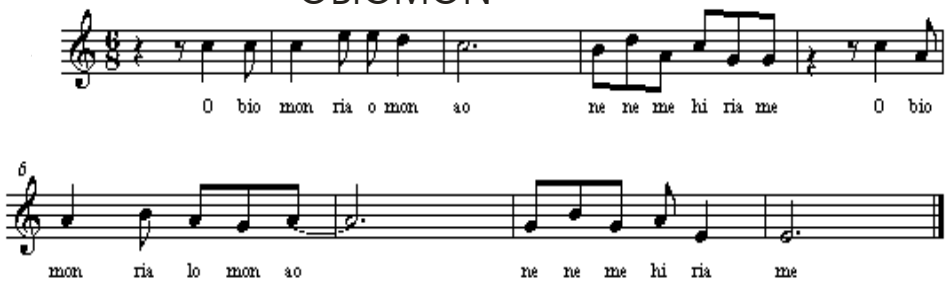

Text in Esan

Obio mon ria omon a

nene men i ria men

Obio mon ria omon a

nene men i ria men

\begin{abstract}
Translation
Mother has spoilt a child.

My mother did not spoil me.

Mother has spoilt a child.

My mother did not spoil me.
\end{abstract}

She could barely dance to the first two songs before she requested for permission to sit down. The remaining three songs were performed for her while she was seated. The style in the therapy sessions was a mixture of individual and group sessions. In the individual session, the priest/healer performed some selected songs for the patient alone. She was encouraged to sing and dance to the songs performed by members of the society . When the patient was too weak to stand or even sit well, members of the society sang and danced while the patient became the spectator. This then turned out to be group session. 


\section{Management}

Two women who are members of the society were put in her charge in the labour ward while priest William Urieto was regularly checking on her in the labour room.

Result: At 5.30am on the 31st of August 2007, Mrs. Obehi Aaron delivered a baby girl.

Follow-up: She stayed with her baby in the healing home for three days before going to her parents' home on the 3rd of September, 2007.

\section{Insomnia}

Insomnia is a condition of being unable to sleep. This is a common accompaniment to mental disorder. The mind is so busy grappling with problems that it is just unable to rest. Efforts to go to sleep are to no avail and the sufferer spends agonizing nights worrying about how he will cope with life (Trevor, 1983:42). Sleeplessness, sleep truncation and early waking, according to Iyayi members, are usually a result of emotional issues bottled up in the mind, which are related to wrong actions against self, friends, relations or the land. Over a period of time, the effect of fear and anxiety concomitant with the wrong deeds begins to manifest. Physiological defects become palpable in the patient's clinical picture. Commenting on fear as a complex emotion which may negatively affect health, Mbanefo (1991:4) said:

Human beings operate on a basis of check and balance system consisting of three departments: the physical, the intellectual and the emotional. When there is harmony in the respective working of the three, the individual is sound and normal. A disabling fault in one of the three creates an imbalance that often appreciably reduces efficiency of the individual (Mbanefo, 1991: 4).

What follows is an account of the procedure used in treating a case of insomnia with music by members of the Iyayi society.

\section{Case Study 2}

Thomas Otobo was born at Ekekhen, Igueben. He was a secondary school drop out who started business early. His elder brother, Peter, was in school when he impregnated Martha, his school mate. Subsequently Martha was given to Peter as a wife. As a young boy who was sponsored by his parents, he was hardly ever able to meet the financial needs of his new status as a married man and student. Thomas then decided to help his brother Peter and his wife financially. As a result of this, Thomas began to have affairs with Martha, his brother's wife. Soon his sin started worrying him and he began to feel unsafe even in the midst of friends. He was afraid to go out at night and he began to experience sleepless nights caused by his wrong actions and thoughts over what would happen if his brother got to know this secret affairs with his wife. 


\section{Diagnosis}

Since he could not find solutions to his problems, Thomas then confided in one of his friends about his sleeplessness. He also informed his friend of how he has spent much money buying medicine which did not improve his situation. It was this friend who then led him to the Iyayi society at Usugbenu on the 12th of May, 2006. On his second visit during worship, a priestess Alice Omondiale pulled him out before the congregation. He was told that he has used his own hands to attract evil which could annihilate a whole lineage if something was not done to avert it. The woman asked him myriads of questions among which were: who is Martha? Where do you know her? He was then told to say to himself "may the trouble coming from Martha's abode not engulf me". Having been prompted by these questions, he recounted the whole story of the secret affairs he has been having with his brother's wife.

\section{Treatment}

After recounting his story, he was asked to return to his village immediately to confess to his people what he has done. As a result of his confession, he was fined a goat which was killed for the propitiation of ancestral spirits. For Martha, ritual cleansing was done for not reporting Thomas' overtures promptly. She was purified by using a chick to cleanse her body after which it was smashed on the floor. She was further required to take an oath of fidelity to her husband after which, she was given a bath which indicates washing sins away. This exercise was supervised by elderly women in the village.

Thomas was then kept in the temple for three days. Every evening for thirty minutes, special music was played for him from 7:30pm to 8:00pm after which he was given a piece of kola nut blessed by the healer/priest to eat. The blessing centered around admonishing the patient and asking God to forgive him of his sins. By the third day, he had recovered and was discharged. The Iyayi repertory for this ailment are songs 'Orehayisiosi', 'Akhumenkhian,' 'Ona Ughele' and 'Ujedugbo' transcribed below.
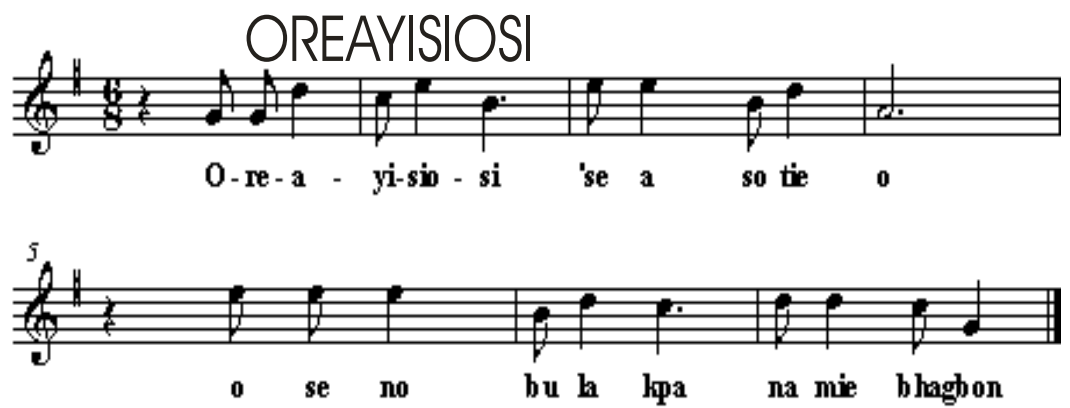

Text in Esan Oare ha yi sho shi Ose ha so tie -o Ose no bula kpa Na mhien bha gbon
Translation

Even if it is the church it is God one calls on it is one God that is in the world 


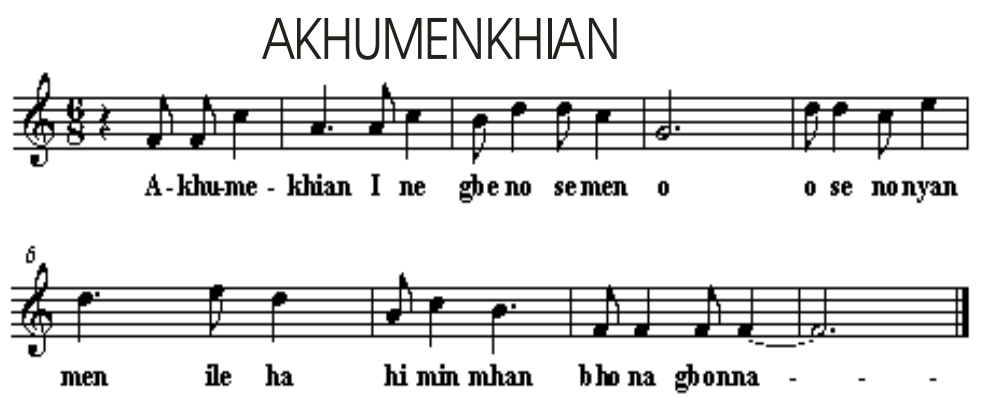

Text in Esan Akhumen Khian Ine gbe no se meo Ose no nyan mhen Ole ha hi mhin me Bho na gbon nan
Translation

They are pursuing me

I have taken refuge in God

It is only God who owns me

that can rescue me

in this life

\section{ONA UGHELE}

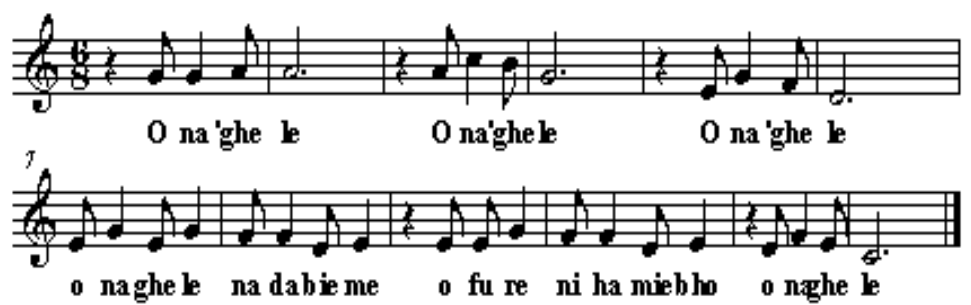

Text in Esan

Ona ughele

Ona ughele

Ona ughele

Ona ughele na de biemen

Ofure ni ge mie bho

it

Ona ughele
Translation

This is the land

This is the land

This is the land

This is the land where I was born

It is peace I will find in

This is the land 


\section{UJEDUGBO}
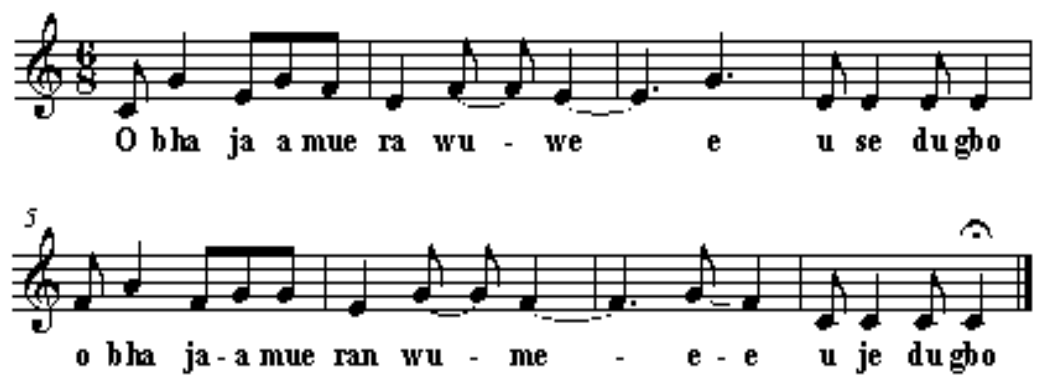

Text in Esan

Uje du gbo

Obha ja mue ran uwu we ee

Uje du gbo

Obho ja ue ran uwu me ee
Translation

The Farm Road

does not allow wood to be carried sideways The farm road

does not allow wood to be carried sideways

\section{Management}

While he was on Iyayi music daily, for three days, Thomas was kept in the healing home. His diet was not altered nor his movement restricted. In Iyayi society, rituals, and music are concomitant. Rituals are added to music to present holistic healing. In some cases, rituals serve placebo effects. In the case being reported, Thomas was routinely given a piece of Kola nut during the three musical sessions held for him.

Result: He became well and was relieved of all forms of fear.

Follow up: Since his discharge, Thomas has been living in Benin and doing well in his business.

\section{Spirit Possession}

Spirit possession is associated with mental disorder capable of distorting a person's reasoning faculty. The behaviours associated with this ailment or disorders are soliloquy, poor dressing, laughing without cause, not responding to instructions and unnecessary hostility. These are abnormal behaviours which cause considerable embarrassment and harm to sufferer of the ailments and even others (Trevor 1983:45). In terms of abnormality, Crooks and Stein (1988:462) remark:

There is no universally accepted definition of abnormality, however, psychologists who specialise in studying abnormal behaviour tend to emphasise a common core of four criteria that may be used to distinguish normal and abnormal behaviour: atypicality, maladaptivity, psychological discomfort and social unacceptability (Crooks and Stein, 1988: 462). 
They explained further that behaviour is atypical when one displays very peculiar conduct or when one's behaviour deviates extremely from the way people act. Maladaptive behaviour has to do with a person's inability to function adequately in every social and occupational role. People suffering from psychological discomfort are often seen to be leaving in their own worlds. They have observable anxiety, depression or agitation which makes them uncomfortable within themselves and among friends. Socially unacceptable behaviours of psychologically disordered people are often judged as culturally unacceptable; for example, a young girl of seventeen who refuses to have a bath for days, eats or tears her clothes and sings throughout the night may be seen as a person who is not enjoying good health. In Esan, spirit possession is often seen as a kind of initiatory sickness. This concept has also been observed by Hart (1990:106), Kongo (1997:9) Friedson, (1997:11) and Nzewi 2002:2) in different African societies.

Initiatory sickness or illness in Esan comes to someone who is a member of a traditional religious group and who is being divinely selected as a healer, priest or priestess. Such a person suffers from one kind of affliction or the other which is seen as a call to service. For instance, among many African religious groups, the healer or medicine man is often a former patient and this is also the case among the Mashawe in Malawi (Chilivumbo, 1972:8). The idea of initiatory sickness or illness surrounds the special selection of master healers. In this regard, Nzewi (2002) explains:

In some African cultures a person who will eventually become a healer is supernaturally selected through signs such as sickness. The signs, which often result in strange behaviour of physiological ill health, manifest irrespective of age and gender. When diagnosed, proposing or capacitating the person to become a healer could entail the medical- musical theatre of opening the inner eyes to perceive beyond the commonly visible or the reception of extraordinary communications (Nzewi, 2002: 2).

These kinds of spirit possession quite often leave the sufferers psychotic and quasipsychiatric. To bring the patient back to a state of well being, Iyayi music is used and exorcism is central to the healing rituals. How healing is done through music in this society is substantiated in the cases reported below.

\section{Healing the Land and members of General Debilities.}

Members of Iyayi society hold the view that the community (land or environment) could become sick due to deliberate act of deviance or corrupt practices. As a result of such development, individuals living in it may begin to experience poor health. To retune the land, all night musical retreat is held to cleanse the land of its impurities and ailments. This is done by singing and dancing around a particular host community while spraying Ere bi umen5 (a mixture of traditional chalk and salt) on the land as they dance through the village. This idea of healing the entire land through music and dance is a common phenomenon among the people of Nigeria. For instance, Ekewenu 
(1996:45) discussed Odegbigba6 ritual in Awankere festival of Warri, while Iyeh et al (2005:131) also discussed Agba Kuro7 ritual in Ichu-Ulor festival of Asaba people of Delta state, Nigeria. Apart from cleansing the land, the performers of the rituals are themselves believed to be given prophylactic treatment.

Rigorous dance movements reduce blood pressure and the risk of heart diseases. During worship, every member of Iyayi society is encouraged to dance off diseases, sweat out ailments and be rejuvenated. It is a medically accepted view that deficiency in tissue salt results from too much water in the body is injurious to the body. However, when members are subjected to constant music and dance performances during worship, sweating occurs and the liquid level reduces. Healing is thus achieved regularly as members dance and sing Iyayi songs. These songs are attested to by both members and non-members as healing general weaknesses, drowsiness and constipation, to mention just a few.

Music therapy as used by the Iyayi society is different from the one used in western praxis. In the west, music therapists are members of the Medical and Dental Councils, they believe that diseases are primarily caused by microbes and they stress clinical approach to healing. In Iyayi society, the healing methods are traditional; this is discernable in the training of music healers, their conception of illness and the healing patterns employed. These healers consider multiple variables in disease causation such as the individual, his lineage, his social life in connection with his environment. It is this encompassing or holistic approach that has given this society eminence in Esan in particular and Edo state in general.

Music making is not restricted to organized sound only; it also includes a symbolic expression of a social and cultural organization, which reflects the values, the past and present ways of life of human beings. Our study of the text of Iyayi songs randomly collected from the field indicates that some of their songs among other things are therapeutic. Their texts speak to the patients and the ailments directly. The patients are further encouraged through songs to imbibe positive thinking about their wellness. This idea is reflected in the song 'Eran hi gbo bhiuku men' - fire cannot burn my brother because if water contacts fire it quenches immediately. Fire in this context is symbolic of ailments and worldly troubles. Obhiuku is member of or child of $U k u-$ this simply refers to the members of the Iyayi fold or persons who have run to them for safety. Water as used in the context is the healing attribute inherent in Iyayi society.

Another song that reflects the healing attribute of Iyayi songs is Egholemianmen. The song addresses sellers of different kinds of ailments, that is, evil forces in the community not to sell diseases to innocent members. To sell ailments as used in this context means in the actual sense, spreading of diseases. The song is indirectly saying that whoever devices evil against the innocent should be consumed by evil machinations.

Musical sound enters the human body primarily through the ears and also, through the pores in the body. This sound goes directly into the pituitary gland which in-turn secretes endorphins directly into the blood to kill pains thus, healing is achieved. Healing is achieved when a patient bathes continuously in the music being performed to the extent of dancing to it, this dance induces sweating and in this process the patient forgets pains he originally had. Through music, patients are afforded the 
opportunity of development of group feeling and socializing with peers, gain relief from self concern and discover avenue for exercise. In Iyayi society, there are certain symbols that are used in healing; they are water, salt, songs, palm kernel oil, and traditional chalk. While in some cases, they are administered orally in some others, they are simply rubbed on the patient's body; these symbols might be different from one community to the other in Nigeria.

\section{Conclusion}

In this paper, we have identified and discussed the members of Iyayi society's concept of illness, its causation and the musical treatment used in treating some selected ailments. From the roles they play in the host community and its environs, it is suggested that Iyayi music holds much promise in health care delivery. It is, therefore, the position of this paper, that similar researches on the use of music for therapeutic purposes be carried out among the various ethnic groups in Nigeria. If any meaningful progress is to be made in the directions above, there must be a synergy between traditional healers, religious leaders, musicologists, anthropologists and medical practitioners.

\section{End Notes}

1. Igbe in Esan is meaningless but to Iyayi devotees, it is the spirit of god, which possesses members causing them to tremble, shiver, and quiver and behave in a strange form ecstatically while giving revelations.

2. Uden is palm kernel oil. It used in the same manner as the anointing oil of Pentecostal churches

3. Ogbon is brownish type of clay.

4. Traditional chalk and salt are viewed as coolants and purifiers in Iyayi society.

5. Spirit possessed people in Iyayi society are often rubbed with traditional chalk it is believed among them to have soothing effect.

6. Ode gbigba ritual sweeping (cleansing) of the streets through music and dance during Awankere festival of the Itsekiri of Delta State.

7. Agbakuro ritual sweeping (cleansing) of the streets through music and dance during Ichulor festival of the Asaba people of Delta State

Aluede, Charles O. \& Iyeh, M. A. 2008, Music and Dance Therapy in Nigeria: The Task before the Potential Nigerian Music Therapists in the Twenty First Century. Voices: A World Forum for Music Therapy. Retrieved April 3, 2008, from http://www.voices.no/ mainissues.

Alvin, J.1975, Music Therapy. London: Hut Chinson

Brandel, R. 1961, The Music of Central Africa: An Ethnomusicological Study. The Hague: Mantins Nighoff.

Crooks, R. L. and Stein, J.1988, Psychology: Science and Life. New York: HoltRinehart \& Winston.

Ekewenu, D.B.1996, The Role of Music in Awankere Festival. Diss. Institute of African Studies. University of İbàdàn.

Erinosho, O.A. 1998, Health Sociology for University, Colleges and Heath related Institution. İbàdàn: Sam Bookman Educational and Commercial Services.

Friedson, S. 1996, Dancing Prophets, Chicago: Chicago University Press.

Hart, M. 1990, Drumming at the Edge of Magic. New York: Harper Collins Publisher. 
Hornby, A.S. 2000, Advanced Learner's Dictionary. London: Oxford University Press.

Iyeh, M.A.\& Aluede, C.O.2006, An Exploration of the Therapeutic Potency of Music in IchuUlor Festival of Asaba People. Nigerian Journal of Musicology. 1.1: 124-142.

Kongo P. Z.1997, Music and Healing in Kongo Area. Western central Africa. Conference Paper. International Centre for African Music and Dance. University of Ghana. Sept. 3-5 1997.

Lambo, T.A.1955, The Role of Cultural Factors in Paranoid Psychosis among the Yoruba tribe. Journal of Mental Science. 101: 239-266.

Lateef, Y. 1989, Hausa Performing Arts and Music. Lagos: Federal Ministry of Information and Culture.

Mbanefo, S.E.1991, Psychiatry in General Medical Practice in Nigeria. Ìbàdàn: Ibadan University Press.

Mechanic, D. 1968, Medical Sociology: A Selective View. New York. Free Press.

Mereni, A.E. 2004, Music Therapy, Concept Scope and Competence. Lagos: Apex Books Limited.

Moreno, J. J. 1995, Ethnomusic Therapy: An Interdisciplinary Approach to Music and Healing. The Arts in Psychotherapy. 22.4: 329 - 338.

Nabofa, M.Y 1973, Igbe Religion in Urhoboland. Project. Religious Studies. University of İbàdàn.

Nabofa, M.Y. 1983, Erhi and Eschatology. Traditional Religion in West Africa. Ed. Adé Adégbolá. İ̀àdàn: Daystar Press.

Nabofa, M.Y. 1996, Faith/Spiritual Healers as Alternative Therapeutics: Success and failures. Readings in Medical Sociology. Eds. Òkè, E.O and Ówùmí, E.O. Ìbàdadn: Resource Development and Management Services. 234-266.

Nabofa, M.Y. 2002, The Use of Dance in Urhobo Belief and Worship. Orita 22.1: 192-106.

Nabofa, M.Y. 2003, Igbe Religious Movement. The Urhobo people. Ed. Otite, O. İbàdàn: Shadon C.I. Ltd. 231-241.

Nzewi, M. 2002, Backcloth to Music and Healing in Traditional African Society. Voices. 2.1: $1-4$

Ohaeri, J.U. 1988, African Traditional Medicine: A Stage in the People's History. African Notes. 12. $1 \times 2: 24-28$.

Okoduwa, A.1997, A Geography of Esan Archeology and Esan Origin. Ed. A. Okoduwa. Studies in Esan History and Culture. Benin: Omon Uwessan Publishers.

Omíbìi-Obidike, M.A. 1998, Music and Healing Among the Yoruba .African Notes. 22. 1x2: $1-53$.

Òsunwọlé, S.A.1990, The Significance of Beliefs and Healing in Yoruba Culture. African Notes. 14. $1 \times 2: 30-36$.

Òsunwọlé, S.A.1996, Disease Diagnosis and Etiology as a System of Thought. Readings in Medical Sociology. Eds. E.O. Òkè, and E.O. Ówùmí. İbàdàn: Resource Development and Management Services. 209-222.

Pavlicevic, M. 2001, Music Therapy in South Africa Compromise as Synthesis? Voices 1.1: $1-2$.

Quarm, O.K.O. 1997, The Akom Healing System of Akam of Ghana. Conference Paper. International Centre For African Music and Dance. University of Ghana. Sept. 3-5th.

Zatorrre, R 2005, Music the Food of Neuroscience. Journal of Nature .434. 312-315. 